\title{
Regulatory expression of components in the BMP pathway in white adipose tissues of cattle
}

\section{$\operatorname{AUTHOR}(\mathrm{S}):$}

Qiao, Yuhang; Yamada, Tomoya; Kanamori, Yohei; Kida, Ryosuke; Shigematsu, Mei; Fujimoto, Yusuke; Tomonaga, Shozo; Matsui, Tohru; Funaba, Masayuki

\section{CITATION:}

Qiao, Yuhang ... [et al]. Regulatory expression of components in the BMP pathway in white adipose tissues of cattle. Livestock Science 2015, 174: 144-149

\section{ISSUE DATE:}

2015-04

URL:

http://hdl.handle.net/2433/198736

\section{RIGHT:}

(c) 2015 Elsevier B.V. Licensed under the Creative Commons Attribution-NonCommercial-NoDerivatives 4.0 International http://creativecommons.org/licenses/by-nc-nd/4.0/. NOTICE: this is the author's version of a work that was accepted for publication in [Livestock Science]. Changes resulting from the publishing process, such as peer review, editing, corrections, structural formatting, and other quality control mechanisms may not be reflected in this document. Changes may have been made to this work since it was submitted for publication. A definitive version was subsequently published in [Livestock Science, Volume 174, Pages 144-149], doi:10.1016/j.livsci.2015.02.008.; 許諾条件により本文ファ イルは2015-02-20に公開;; この論文は出版社版でありません。引用の際には出版社版をご確認ご利用ください。; This is not the published version. Please cite only the published version. 
1 Regulatory expression of components in the BMP pathway in white 2 adipose tissues of cattle

3

4 Yuhang Qiao ${ }^{1 \star}$, Tomoya Yamada ${ }^{2 \star}$, Yohei Kanamori ${ }^{1}$, Ryosuke Kida ${ }^{1}$,

5 Mei Shigematsu ${ }^{1}$, Yusuke Fujimoto $^{1}$, Shozo Tomonaga $^{1}$,

6 Tohru Matsui $^{1}$ and Masayuki Funaba ${ }^{1 \dagger}$

7

$8{ }^{1}$ Division of Applied Biosciences, Graduate School of Agriculture, Kyoto University,

9

${ }^{*}$ These authors equally contributed to this study.

${ }^{\dagger}$ To whom correspondence should be addressed:

Masayuki Funaba, Ph.D.

Division of Applied Biosciences

Graduate School of Agriculture

Kyoto University

Kitashirakawa Oiwakecho, Kyoto 606-8502, Japan

Tel: +81-75-753-6055

Fax: +81-75-753-6344

E-mail: mfunaba@kais.kyoto-u.ac.jp 


\section{Abstract}

25 The BMP pathway is known to positively regulate murine brown adipogenesis. The

26 present study examined the mRNA levels of BMPs and activin $\beta \mathrm{B}$ as well as receptors

27 for the BMP pathway in the adipose tissues of cattle fed diets with differential ratio of concentrate to roughage or vitamin A-deficient diet. The expression of activin $\beta \mathrm{B}$ was significantly increased in the subcutaneous fat depot of animals fed the concentrate diet, while the vitamin A-deficient diet significantly increased the expression of BMP4 in the mesenteric fat depot. The expression of receptors for the BMP pathway, ALK2, ALK3, ActRIIA, and BMPR2, showed a similar pattern to that of BMP4 and activin $\beta \mathrm{B}$ in response to the dietary treatments. The results of the present study suggest that diet modulates expression of BMP pathway and may be responsible for the regulatory expression of brown/beige adipocyte-related genes in the adipose tissues of cattle.

Keywords: BMP; brown adipocyte; beige adipocyte; cattle 


\section{Introduction}

Brown/beige adipocytes dissipate chemical energy in the form of heat (Cannon and Nedergaard, 2004; Shabalina et al., 2013); the expression of uncoupling protein 1 (Ucp1), a proton channel located on the inner mitochondrial membrane, enables brown/beige adipocytes to expedite energy (Cannon and Nedergaard, 2004). In mice, brown adipose tissue located in the interscapular region is composed of brown adipocytes (Smorlesi et al., 2012), whereas beige adipocytes, also known as brite adipocytes, are sparsely distributed in various white adipose tissues including subcutaneous, mesenteric and epididymal fat depots (Ishibashi and Seale, 2010). Molecular signatures revealed a distinct pattern between brown adipocytes and beige adipocytes, suggesting that the origin of these two adipocytes differ (Wu et al., 2013).

We previously reported Ucp1-positive adipocytes in the white adipose tissues of cattle (Asano et al., 2013). Furthermore, the diet affected the expression levels of genes predominantly expressed in brown/beige adipocytes more than those expressed in white adipocytes (Seale et al., 2007; Sharp et al., 2012) in the fat depots of cattle (Asano et al., 2013; Kanamori et al., 2014); the genes included Ucp1, Cidea, Dio2, Cox1 and Cox8b (Asano et al., 2013; Kanamori et al., 2014). Based on the close relationship between the expression levels of brown/beige adipocyte-related genes and brown/beige adipocyte activity (Seale et al., 2008; Tseng et al., 2008; Barbatelli et al., 2010; Yadav et al., 2011; Whittle et al., 2012), these findings suggest that diet may modulate energy expenditure in the brown/beige adipocytes of cattle. Beef cattle are raised as industrial animals, and fattening efficiency is one of the determining factors of the economy of beef production. Therefore, the activation of brown/beige adipocytes is desirably avoided because their activation may decrease fattening efficiency, the ratio of body weight gain to feed consumed. 
66

The differentiation of brown/beige preadipocytes is regulated by the bone morphogenetic protein (BMP) pathway (Tseng et al., 2008; Schulz et al., 2011; Elsen et al., 2014; Xue et al., 2014). BMP7 was previously shown to stimulate brown adipogenesis (Tseng et al., 2008; Schulz et al., 2011), and BMP4 was recently reported to induce differentiation into brown/beige adipocytes (Elsen et al., 2014; Xue et al., 2014). We hypothesized that the diet-induced modulation of the expression of brown/beige adipocyte-related genes is involved in the activity of the BMP pathway. The induction of ligands and their signaling components often occurs as a positive regulation of BMP signaling (Miyazono et al., 2000). Therefore, the present study examined the expression levels of components that elicit BMP signaling in the adipose tissues of cattle fed a roughage diet or concentrate diet, and a control or vitamin A-deficient diet. In previous studies, the expression levels of brown/beige adipocyte-related genes were modulated by the diets (Asano et al., 2013; Kanamori et al., 2014).

\section{Materials and methods}

\subsection{Animals and feeds}

Sixteen Japanese Black steers were used in the present study. Dietary treatments were the same as those reported by Yamada and Nakanishi (2012) and Asano et al. (2013) for experiment (Exp) 1 and Yamada et al. (2013) and Kanamori et al. (2014) for Exp 2.

Briefly, in Exp 1, 10-month-old steers were allotted by body weight to one of two groups: a roughage diet group $(n=4)$ or concentrate diet group $(n=4)$. The roughage diet consisted of 35\% roughage (orchard grass hay) and 65\% concentrate mixture consisting of corn, barley, wheat bran, rice bran, and soybean meal (Nasuno for Wagyu Fattening; JA Higashi-nihon Kumiai Shiryou, Ota, Gunma, Japan), whereas the 
93

concentrate diet contained $10 \%$ roughage and $90 \%$ concentrate mixture on a total digestible nutrients (TDN) basis.

In Exp 2, 10-month-old steers were allotted by body weight to one of two groups: a control group $(n=4)$ or vitamin A-deficient group $(n=4)$. Two kinds of fermented total mixed ration (TMR) containing whole crop rice silage, fermented byproducts (beer cake and tofu cake), and concentrate, i.e., TMR-A and TMR-B, were prepared in a TMR center, and used as a control diet. The content of $\beta$-carotene was $7 \mathrm{mg} / \mathrm{kg}$ and $16 \mathrm{mg} / \mathrm{kg}$ for TMR-A and TMR-B, respectively. TMR-A and TMR-B were given to steers aged 10-20 months and 21-30 months, respectively. The steers in the vitamin A-deficient group were fed orchard grass hay ( $0.5 \mathrm{mg} / \mathrm{kg}$ of $\beta$-carotene) and a concentrate mixture consisting of corn, barley, wheat bran, rice bran, and soybean meal $(0.1 \mathrm{mg} / \mathrm{kg}$ of $\beta$-carotene, Nasuno for Wagyu Fattening; JA Higashi-nihon Kumiai Shiryou, Ota, Gunma, Japan). The supplied dry matter amount of orchard grass hay in the vitamin A-deficient group was matched to that of whole crop rice silage in the control diet to equalize the ratio of roughage to concentrate between the two groups.

Feeds were provided to steers to equalize TDN intake for 20 months between groups in both experiments. Subcutaneous and mesenteric adipose tissues were collected at 30 months of age (Yamada and Nakanishi, 2012; Yamada et al., 2013). All animals received humane care as outlined in the Guide for the Care and Use of Experimental Animals (National Institute of Livestock and Grassland Science, \#09032638 for Exp 1 and \#10032404 for Exp 2).

\subsection{RNA isolation and RT-quantitative $P C R$}

Total RNA isolation, cDNA synthesis, and real-time RT-quantitative PCR (RT-qPCR) were conducted as described by Asano et al. (2013). The cDNA synthesized from 5 or 
10 ng of total RNA was subjected to RT-qPCR analyses as the template. Ct values were determined, and the abundance of gene transcripts was analyzed by the ${ }^{\Delta} \mathrm{Ct}$ method using Hprt1 as the corrected gene (Duran et al., 2005). Gene expression in the roughage diet group (Exp 1) or control group (Exp 2) in each fat depot was set to 100. The nucleotide sequence of qPCR primers, size of qPCR product, and mean Ct value in the subcutaneous fat depot are shown in Table 1.

\subsection{Statistical analyses}

Data are expressed as the mean \pm SE. Data on gene expression were log-transformed to provide an approximation of a normal distribution before analyses. Differences between dietary groups were examined by the unpaired $t$-test using Microsoft Excel ${ }^{\circledR}$. Differences of $P<0.05$ were considered significant. A slight difference was considered to be present when $0.05 \leq P<0.10$.

\section{Results}

Effects of dietary ratio of roughage to concentrate on the gene expression of BMPs and activin $\beta \mathrm{B}$ in the adipose tissues of cattle were examined in Exp. 1 (Fig. 1A). The expression of activin $\beta \mathrm{B}$ in the subcutaneous fat depot was significantly higher $(P=$ 0.007) in the concentrate diet group than in the roughage diet group. The expression of BMP4 tended to be higher in the concentrate diet group $(P=0.06)$. In contrast, no significant differences were observed in the expression of these ligands in the mesenteric fat depot between the dietary groups. Exp 2 examined the effects of a dietary vitamin A deficiency (Fig. 1B). The expression of BMP4 in the mesenteric fat depot was significantly increased by feeding the vitamin A-deficient diet $(P=0.02)$. In addition, the expression of activin $\beta \mathrm{B}$ tended to be higher in the vitamin A-deficient diet group $(P=0.07)$. The expression of BMP7 was 20 -fold higher in the vitamin 
147 A-deficient diet group than in the control diet group, although not significantly so 148 because of large variations in the vitamin A-deficient diet group $(P=0.18)$. The vitamin 149 A-deficient diet did not affect the expression levels of BMPs or activin $\beta B$ in the 150 subcutaneous fat depot. The diet-related changes in gene expression were not a non-specific event, because the expression of fatty acid synthase (FAS) was not significantly changed by the diets (Fig. 2). Expression of TGF- $\beta 1$ in the fat depots was also unchanged, and similar changes were observed in the expression levels by the diets when $\beta 2$-macroglobulin was used as a corrected gene (data not shown). The Ct value of BMPs and activin $\beta$ B was relatively larger than that of FAS (Table 1), suggesting lower expression of BMPs and activin $\beta$ B than that of FAS.

BMP signals through complex formation with the type I receptor and type II receptor (Miyazono et al., 2010); ALK2 and ALK3 are BMP type I receptors, while ActRIIA, ActRIIB and BMPR2 are BMP type II receptors (Miyazono et al., 2010). The expression of ALK2 and ALK3 in the subcutaneous fat depot tended to be higher in the concentrate diet group than in the roughage diet group $(P=0.07$ and $P=0.09$, respectively), whereas no significant differences were observed in expression levels in the mesenteric fat depot between the groups (Fig. 3A). The vitamin A deficiency did not affect the expression of BMP receptors in the subcutaneous fat depot (Fig. 3B). However, the vitamin A-deficient diet significantly or tended to increase the expression of ALK2 $(P=0.03)$, ALK3 $(P=0.03)$, ActRIIA $(P=0.04)$, and BMPR2 $(P=0.05)$ in the mesenteric fat depot. Significant changes in the expression of ActRIIB were not detected in the adipose tissues (data not shown). 
173 Brown adipogenesis is stimulated by the activation of the BMP pathway (Tseng et al., 2008; Schulz et al., 2011; Elsen et al., 2014; Xue et al., 2014). Signal activity of the BMP pathway is often regulated at the mRNA level of components involved in the signal (Miyazono, 2000). Previously, we reported that the expression of Ucp1 in the subcutaneous fat depot, but not the mesenteric fat depot was higher in cattle fed a concentrate diet than in those fed a roughage diet (Asano et al., 2013). Furthermore, the expression levels of brown/beige adipocyte-related genes (Seale et al., 2007) in the mesenteric fat depot were generally higher in cattle fed the vitamin A-deficient diet than in those fed the control diet, whereas these expression levels in the subcutaneous fat depot was similar between the groups (Kanamori et al., 2014). Taken the evidence, we hypothesized that expression levels of the components of the BMP pathway are changed in the fat depots of cattle fed diets with different ratio of roughage to concentrate or vitamin A-deficient diet. We evaluated the mRNA levels of molecules that elicit BMP signaling. In addition to BMP4 and BMP7, we examined the expression level of activin $\beta \mathrm{B}$. The signal transduction of activin $\mathrm{B}$, a homodimer of the activin $\beta \mathrm{B}$ subunit, has not yet been elucidated in detail; activin B signals in a similar manner to activin A, a structurally related molecule (Tsuchida et al., 2004), but also transmits BMP-mediated signals (Besson-Fournier et al., 2012). The present study revealed that the expression levels of BMP4, activin $\beta \mathrm{B}$ and BMP receptors were up-regulated in the subcutaneous fat depot of cattle fed the concentrate diet and in the mesenteric fat depot of cattle fed the vitamin A-deficient diet. The present results suggest that the modulation of expression levels of brown/beige adipocyte-related genes in the fat depots of cattle shown in previous studies (Asano et al., 2013; Kanamori et al., 2014) was achieved by altered activity of the BMP pathway.

In humans, expression levels of the components of the BMP pathway in adipose tissue appear to be related to adiposity. The expression level of activin $\beta B$ in adipose tissue 
200

201

202

203

204

205

206

207

208

209

210

211

212

213

was previously shown to be higher in obese humans than in lean humans, and was decreased by reductions in body weight (Sjoholm et al., 2006). A negative relationship has been reported between BMP4 expression levels in adipose tissue and body mass index (Qian et al., 2013). Furthermore, the expression levels of ALK3 and BMPR2 in adipose tissue were found to be higher in obese humans than in lean humans (Böttcher et al., 2009; Schleintz et al., 2011). The carcass composition of cattle used in this study was similar between the dietary groups because they were pair-fed to equalize TDN intake (Yamada and Nakanishi, 2012; Yamada et al., 2013). Nevertheless, these diets significantly affected the expression levels of molecules involved in the BMP pathway in the adipose tissues of cattle. This altered gene expression may reflect an intrinsic effect of the diet, but not adiposity.

Size of white adipocytes was changed in fattening cattle used in this study (Yamada and Nakanishi, 2012; Yamada et al., 2013); white adipocytes were smaller in cattle fed the concentrate diet and the vitamin A-deficient diet. Considering that the number of beige adipocytes related to the decrease in cell size of white adipocytes in mice (Qian et al., 2013), the stimulation of the BMP pathway through increased expression of the signaling components may induce emergence or activation of brown/beige adipocytes, leading to decrease in adipocyte size of cattle fed the concentrate diet or vitamin A-deficient diet. Generally, adiposity is closely related to the increased size of white adipocytes (Tchermof and Despres, 2013). However, as described above, the carcass composition of cattle was not significantly altered by the diets (Yamada and Nakanishi, 2012; Yamada et al., 2013). It is possible that fat deposition evaluated by carcass analyses is relatively insensitive to clarify effects of diet under the condition of pair-fed on TDN intake. In fact, expression level of FAS was not affected by the diets.

The present study clarified that expression of components of the BMP pathway was 
227 changed by the diets in an anatomical location-dependent manner. The reason why the diet effect was different between fat depots is unclear. Development of adipose tissue in ruminants depends on its anatomical location (Alexander, 1978; Bonnet et al., 2010). Growth of adipose tissue is also dependent on breed of cattle (Landis et al., 2002). Basically, brown adipose tissue is developed during fetal period in cattle, whereas white adipose tissue grows mainly after birth (Bonnet et al., 2010). The differential development of adipose tissue depending on its anatomical location may be responsible for diet-related modulation of expression levels of genes involved in the BMP pathway. As compared with modulation of the ratio of roughage to concentrate, feeding the vitamin A-deficient diet induces severer nutritional restriction. It is possible that the extent in nutritional modulation is responsible for the differences of the affected fat depot.

Feeding vitamin A-deficient diet increased plasma concentration of 8-isoprostane, a marker of oxidative stress, in cattle (Yamada et al., 2013). Mitochondrial uncoupling mediated by Ucp1 expression reduces production of reactive oxygen species, suggesting that Ucp1 expression in brown adipocytes has a role in prevention of oxidative stress (Oelkrog et al., 2014). It is possible that increased expression of genes involved in the BMP pathway reflects defensive reaction to oxidative stress induced by vitamin A-deficient diet.

Prdm16 is a master regulator of the development of brown adipocytes as well as the emergence of beige adipocytes (Seale et al., 2008, 2011). The expression level of Prdm16 in the subcutaneous, but not mesenteric fat depot was shown to be higher in the concentrate diet group than in the roughage diet group (Asano et al., 2013). The vitamin A-deficient diet also increased Prdm16 expression in the mesenteric fat depot, but not in the subcutaneous fat depot (Kanamori et al., 2014). The up-regulation of Prdm16 
254

expression by BMP4 and BMP7 in brown preadipocytes as well as mesenchymal stem cells (Tseng et al., 2008; Xue et al., 2014) suggests that activation of the BMP pathway may induce browning, which is defined as an increase in the mRNA levels of brown/beige adipocyte-related genes, including Ucp1 (Fisher et al., 2012; Nedergaard and Cannon, 2014), in the fat depots of cattle through the up-regulation of Prdm16 expression. Further studies are needed to clarify dietary factor(s) affecting the expression levels of molecules for the BMP pathway and cells affected by dietary factor(s).

\section{Acknowledgement}

This work was supported by a Grant-in-Aid for Scientific Research (23580368 and 26292137) from The Japan Society for the Promotion of Science.

\section{Conflict of interest statement}

Authors of this manuscript certify that there is no conflict of interest.

\section{References}

Alexander, G., 1978. Quantitative development of adipose tissue in foetal sheep. Aust. J. Biol. Sci. 31, 489-504.

Asano, H., Yamada, T., Hashimoto, O., Umemoto, T., Sato, R., Ohwatari, S., Kanamori, Y., Terachi, T., Funaba, M., Matsui, T., 2013. Diet-induced changes in Ucp1 expression in bovine adipose tissues. Gen. Comp. Endocrinol. 184, 87-92.

Barbatelli, G., Murano, ～I., Madsen, ～L., Hao, Q Q., Jimenez, ～M., Kristiansen, K., Giacobino, J.P., De Matteis, R., Cinti, S., 2010. The emergence of cold-induced brown adipocytes in mouse white fat depots is determined predominantly by white to brown adipocyte transdifferentiation. Am. J. Physiol. 
Endocrinol. Metab. 298, E1244-E1253.

Besson-Fournier, C., Latour, C., Kautz, L., Bertrand, J., Ganz, T., Roth, M.P., Coppin, H., 2012. Induction of activin B by inflammatory stimuli up-regulates expression of the iron-regulatory peptide hepcidin through Smad1/5/8 signaling. Blood 120, 431-439.

Bonnet, M., Cassar-Malek, I., Chilliard, Y., Picard, B., 2010. Ontogenesis of muscle and adipose tissues and their interactions in ruminants and other species. Animal 4, 1093-1109.

Böttcher, Y., Unbehauen, H., Klöting, N., Ruschke, K., Körner, A., Schleinitz, D., Tönjes, A., Enigk, B., Wolf, S., Dietrich, K., Koriath, M., Scholz, G.H., Tseng, Y.H., Dietrich, A., Schön, M.R., Kiess, W., Stumvoll, M., Blüher, M., Kovacs, P., 2009. Adipose tissue expression and genetic variants of the bone morphogenetic protein receptor 1A gene (BMPR1A) are associated with human obesity. Diabetes 58, 2119-2128.

Cannon, B., Nedergaard, J., 2004. Brown adipose tissue: function and physiological significance. Physiol. Rev. 84, 277-359.

Duran, E.M., Shapshak, P., Worley, J., Minagar, A., Ziegler, F., Haliko, S., Moleon-Borodowsky, I., Haslett, P.A., 2005. Presenilin-1 detection in brain neurons and FOXP3 in peripheral blood mononuclear cells: normalizer gene selection for real time reverse transcriptase pcr using the deltadeltaCt method. Front Biosci. 10, 2955-2965.

Elsen, M., Raschke, S., Tennagels, N., Schwahn, U., Jelenik, T., Roden, M., Romacho, T., Eckel, J., 2014. BMP4 and BMP7 induce the white-to-brown transition of primary human adipose stem cells. Am. J. Physiol. Cell Physiol. 306, C431-C440.

Fisher, F.M., Kleiner, S., Douris, N., Fox, E.C., Mepani, R.J., Verdeguer, F., Wu, J., Kharitonenkov, A., Flier, J.S., Maratos-Flier, E., Spiegelman, B.M., 2012. FGF21 regulates PGC-1 $\alpha$ and browning of white adipose tissues in adaptive 
thermogenesis. Genes Dev. 26, 271-281.

Ishibashi, J., Seale, P., 2010. Beige can be slimming. Science 328, 1113-1114.

Kanamori, Y., Yamada, T., Asano, H., Kida, R., Qiao, Y., Abd Eldaim, M.A., Tomonaga, S., Matsui, T., Funaba, M., 2014. Effects of vitamin A status on expression of Ucp1 and brown/beige adipocyte-related genes in white adipose tissues of beef cattle. J. Vet. Med. Sci. 76, 1261-1265.

Landis, M.D., Carstens, ～G.E., McPhail, ～E.G., Randel, R.D., Green, K.K., Slay, L., Smith, S.B., 2002. Ontogenic development of brown adipose tissue in Angus and Brahman fetal calves. J. Anim. Sci. 80, 591-601.

Miyazono, K., 2000. Positive and negative regulation of TGF- $\beta$ signaling. J. Cell Sci. 113, 1101-1109.

Miyazono, K., Kamiya, Y., Morikawa, M., 2010. Bone morphogenetic protein receptors and signal transduction. J. Biochem. 147, 35-51.

Nedergaard, J., Cannon, B., 2014. The browning of white adipose tissue: some burning issues. Cell Metab. 20, 396-407.

Oelkrug, R., Götze, N., Meyer, C.W., Jastroch, M., 2014. Antioxidant properties of UCP1 are evolutionarily conserved in mammals and buffer mitochondrial reactive oxygen species. Free Radic. Biol. Med. 77, 210-216.

Qian, S.W., Tang, Y., Li, X., Liu, Y., Zhang, Y.Y., Huang, H.Y., Xue, R.D., Yu, H.Y., Guo, L., Gao, H.D., Liu, Y., Sun, X., Li, Y.M., Jia, W.P., Tang, Q.Q., 2013. BMP4-mediated brown fat-like changes in white adipose tissue alter glucose and energy homeostasis. Proc. Natl. Acad. Sci. USA 110, E798-E807.

Schleinitz, D., Klöting, N., Böttcher, Y., Wolf, S., Dietrich, K., Tönjes, A., Breitfeld, J., Enigk, B., Halbritter, J., Körner, ～A., Schön, ～M.R., Jenkner, J., Tseng, Y.H., Lohmann, T., Dressler, M., Stumvoll, M., Blüher, M., Kovacs, P., 2011. Genetic and evolutionary analyses of the human bone morphogenetic protein receptor 2 (BMPR2) in the pathophysiology of obesity. PLoS One 6, e16155. 
Schulz, T.J., Huang, T.L., Tran, T.T., Zhang, H., Townsend, K.L., Shadrach, J.L., Cerletti, M., McDougall, L.E., Giorgadze, N., Tchkonia, T., Schrier, D., Falb, D., Kirkland, J.L., Wagers, A.J., Tseng, Y.H., 2011. Identification of inducible brown adipocyte progenitors residing in skeletal muscle and white fat. Proc. Natl. Acad. Sci. USA 108, 143-148.

Seale, P., Bjork, B., Yang, W., Kajimura, S., Chin, S., Kuang, S., Scimè, A., Devarakonda, S., Conroe, H.M., Erdjument-Bromage, H., Tempst, P., Rudnicki, M.A., Beier, D.R., Spiegelman, B.M., 2008. PRDM16 controls a brown fat/skeletal muscle switch. Nature 454, 961-967.

Seale, P., Conroe, H.M., Estall, J., Kajimura, S., Frontini, A., Ishibashi, J., Cohen, P., Cinti, S., Spiegelman, B.M., 2011. Prdm16 determines the thermogenic program of subcutaneous white adipose tissue in mice. J. Clin. Invest. 121, 96-105.

Seale, P., Kajimura, S., Yang, W., Chin, S., Rohas, L.M., Uldry, M., Tavernier, G., Langin, D., Spiegelman, B.M., 2007. Transcriptional control of brown fat determination by PRDM16. Cell Metab. 6, 38-54.

Shabalina, I.G., Petrovic, N., de Jong, J.M., Kalinovich, A.V., Cannon, B., Nedergaard, J., 2013. UCP1 in brite/beige adipose tissue mitochondria is functionally thermogenic. Cell Rep. 5, 1196-1203.

Sharp, L.Z., Shinoda, K., Ohno, H., Scheel, D.W., Tomoda, E., Ruiz, L., Hu, H., Wang, L., Pavlova, Z., Gilsanz, V., Kajimura, S., 2012. Human BAT possesses molecular signatures that resemble beige/brite cells. PLoS One 7, e49452.

Sjöholm, K., Palming, J., Lystig, T.C., Jennische, E., Woodruff, T.K., Carlsson, B., Carlsson, L.M., 2006. The expression of inhibin $\beta \mathrm{B}$ is high in human adipocytes, reduced by weight loss, and correlates to factors implicated in metabolic disease. Biochem. Biophys. Res. Commun. 344, 1308-1314. 
Smorlesi, A., Frontini, A., Giordano, A., Cinti, S., 2012. The adipose organ: white-brown adipocyte plasticity and metabolic inflammation. Obes. Rev. 13 Suppl 2, 83-96.

Tchernof A, Després JP. Pathophysiology of human visceral obesity: an update. Physiol Rev. 2013 93:359-404.

Tseng, Y.H., Kokkotou, E., Schulz, T.J., Huang, T.L., Winnay, J.N., Taniguchi, C.M., Tran, T.T., Suzuki, R., Espinoza, D.O., Yamamoto, Y., Ahrens, M.J., Dudley, A.T., Norris, A.W., Kulkarni, R.N., Kahn, C.R., 2008. New role of bone morphogenetic protein 7 in brown adipogenesis and energy expenditure. Nature 454, 1000-1004.

Tsuchida, K., Nakatani, M., Yamakawa, N., Hashimoto, O., Hasegawa, Y., Sugino, H., 2004. Activin isoforms signal through type I receptor serine/threonine kinase ALK7. Mol. Cell. Endocrinol. 220, 59-65.

Whittle, A.J., Carobbio, S., Martins, L., Slawik, M., Hondares, E., Vázquez, M.J., Morgan, D., Csikasz, R.I., Gallego, R., Rodriguez-Cuenca, S., Dale, M., Virtue, S., Villarroya, F., Cannon, B., Rahmouni, K., López, M., Vidal-Puig, A., 2012. BMP8B increases brown adipose tissue thermogenesis through both central and peripheral actions. Cell 149, 871-885.

Wu, J., Cohen, P., Spiegelman, B.M. 2013. Adaptive thermogenesis in adipocytes: is beige the new brown? Genes Dev. 27, 234-250.

Xue, R., Wan, Y., Zhang, S., Zhang, Q., Ye, H., Li, Y., 2014. Role of bone morphogenetic protein 4 in the differentiation of brown fat-like adipocytes. Am. J. Physiol. Endocrinol. Metab. 306, E363-E372.

Yadav, H., Quijano, C., Kamaraju, A.K., Gavrilova, O., Malek, R., Chen, W., Zerfas, P., Zhigang, D., Wright, E.C., Stuelten, C., Sun, P., Lonning, S., Skarulis, M., Sumner, A.E., Finkel, T., Rane, S.G., 2011. Protection from obesity and diabetes by blockade of TGF- $\beta /$ Smad3 signaling. Cell Metab. 14, 67-79.

Yamada, T., Higuchi, M., Nakanishi, N., 2013. Plasma 8-isoprostane concentrations and 
387

388

389

390

391

392

393

394

adipogenic and adipokine gene expression patterns in subcutaneous and mesenteric adipose tissues of fattening Wagyu cattle. J. Vet. Med. Sci. 75, 1021-1027.

Yamada, T., Nakanishi, N., 2012. Effects of the roughage/concentrate ratio on the expression of angiogenic growth factors in adipose tissue of fattening Wagyu steers. Meat Sci. 90, 807-813. 
395

396

397

398

399

400

401

402

403

404

405

406

407

408

409

410

411

412

413

414

415

416

417

418

419

420

421

\section{Figure legends}

Fig. 1. Expression of BMP4, BMP7, and activin $\beta B$ in white fat depots of cattle

(A) In Exp 1, cattle were fed either a roughage diet or concentrate diet for 20 months.

(B) In Exp 2, cattle were fed either a control diet or vitamin A-deficient diet for 20 months. At 30 months of age, subcutaneous and mesenteric white fat depots were collected, and the mRNA levels of BMP4, BMP7, and activin $\beta$ B were examined by RT-qPCR. Expression was normalized to that of Hprt1, and gene expression in each fat depot in the roughage diet group (A) or control diet group (B) was set to 100. Data are shown as the mean \pm SE $(\mathrm{n}=4) . \dagger,{ }^{*}$ and $* *: P<0.10,0.05$ and $P<0.01$, respectively.

Fig. 2. Expression of FAS in white fat depots of cattle

(A) In Exp 1, cattle were fed either a roughage diet or concentrate diet for 20 months.

(B) In Exp 2, cattle were fed either a control diet or vitamin A-deficient diet for 20 months. At 30 months of age, subcutaneous and mesenteric white fat depots were collected, and the mRNA level of FAS was examined by RT-qPCR. Expression was normalized to that of Hprt1, and gene expression in each fat depot in the roughage diet group (A) or control diet group (B) was set to 100. Data are shown as the mean \pm SE (n $=4)$.

Fig. 3. Expression of receptors transmitting BMP signals in white fat depots of cattle

(A) In Exp 1, cattle were fed either a roughage diet or concentrate diet for 20 months.

(B) In Exp 2, cattle were fed either a control diet or vitamin A-deficient diet for 20 months. At 30 months of age, subcutaneous and mesenteric white fat depots were collected, and the mRNA levels of receptors for the BMP pathway were examined by RT-qPCR. Expression was normalized to that of Hprt1, and gene expression in each fat depot in the roughage diet group (A) or control diet group (B) was set to 100. Data are 
422 shown as the mean \pm SE $(\mathrm{n}=4) . \dagger$ and $*$ : $P<0.10$ and 0.05 , respectively.

423 


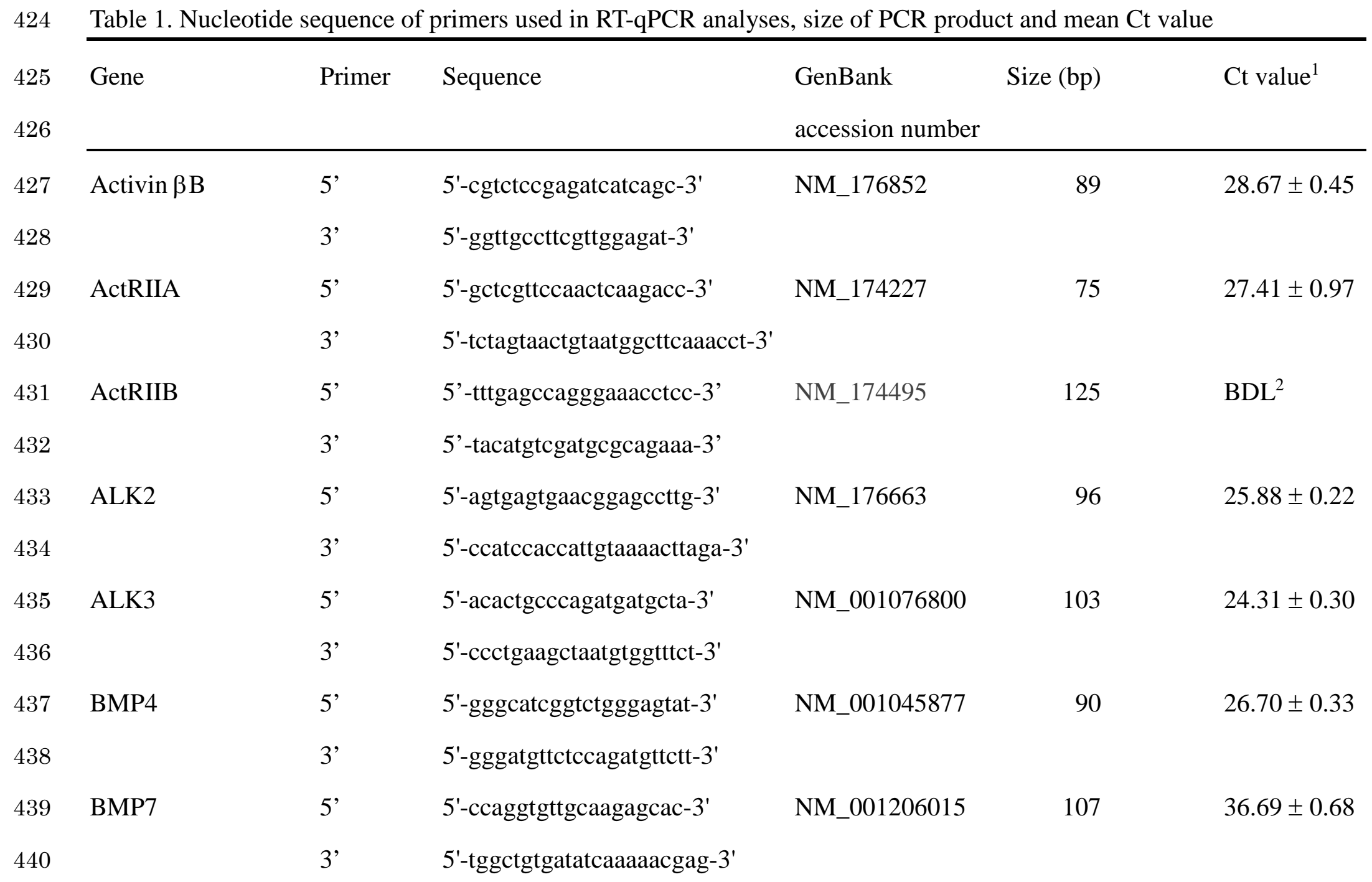




\begin{tabular}{|c|c|c|c|c|c|}
\hline $441 \quad$ BMPR2 & 5 & 5'-tcagagccctctcttgacct-3' & XM_002685492 & 106 & $29.10 \pm 0.61$ \\
\hline 442 & 3 & 5'-cagcaactggacgttcatctaa-3' & & & \\
\hline FAS $^{3}$ & 5 & 5'-cggtgtggacatggtgac-3' & NM_001012669 & 64 & $21.33 \pm 0.70$ \\
\hline 444 & 3 & 5'-ccgaggcaggccatatagt-3' & & & \\
\hline Hprt1 & 5 & 5'-gtgattagcgatgatgaaccag-3' & NM_001034035 & 95 & $22.99 \pm 0.20$ \\
\hline 446 & $3^{\prime}$ & 5'-ccatgaggaataaacaccttctc-3' & & & \\
\hline$\beta 2$-microglobulin & 5 & 5'-catgtccatgtttgaccttcc-3' & NM_173893 & 70 & $19.13 \pm 0.34$ \\
\hline 448 & $3^{\prime}$ & 5'-tcttccccacctctaagatgc-3' & & & \\
\hline TGF- $\beta 1$ & 5 & 5'-cctgctgaggctcaagttaaa-3' & NM_001166068 & 78 & $26.44 \pm 0.59$ \\
\hline 450 & 3 & 5'-aggtagcgccaggaattgt-3' & & & \\
\hline
\end{tabular}

$451{ }^{1}$ Mean \pm SE of expression in the subcutaneous fat depot. ${ }^{2}$ BDL: below detection limit. ${ }^{3}$ For RT-qPCR analyses, cDNA 452 synthesized from $5 \mathrm{ng}$ of total RNA was used as the template; for the other genes, cDNA corresponding to $10 \mathrm{ng}$ of total 453 RNA was used. 
A

B
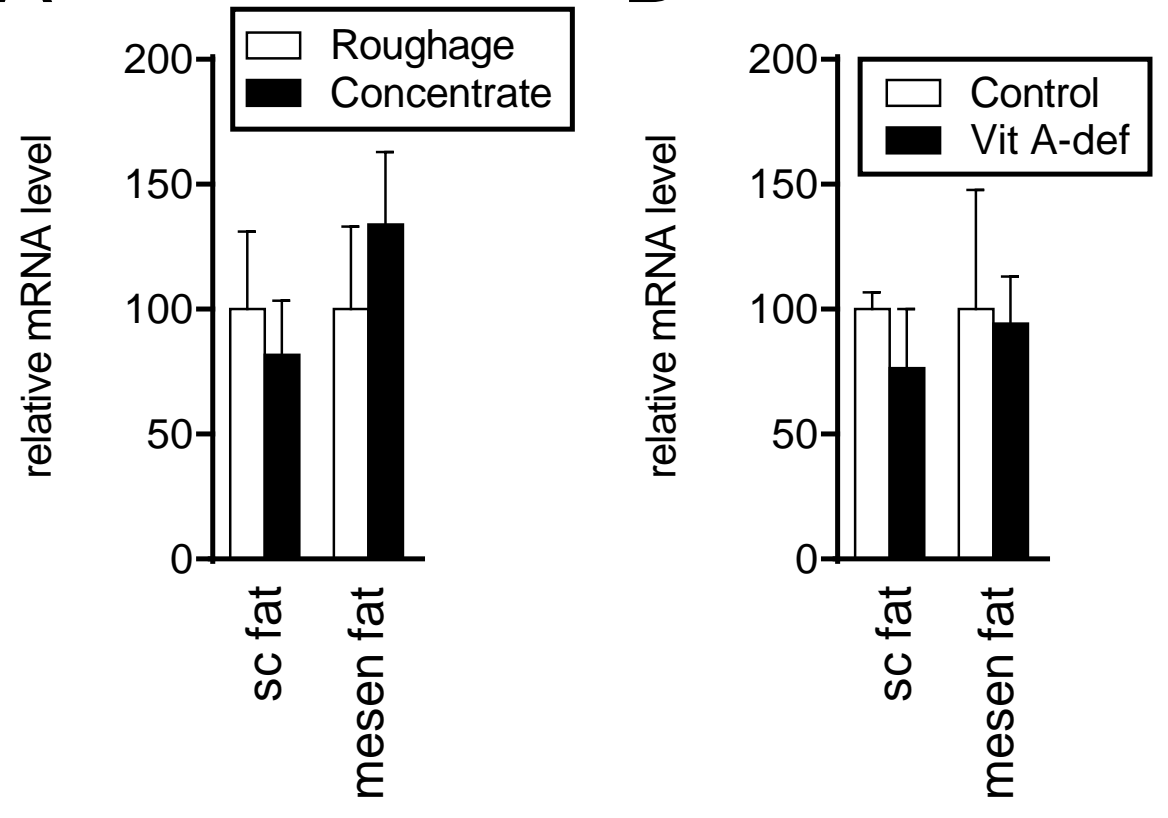

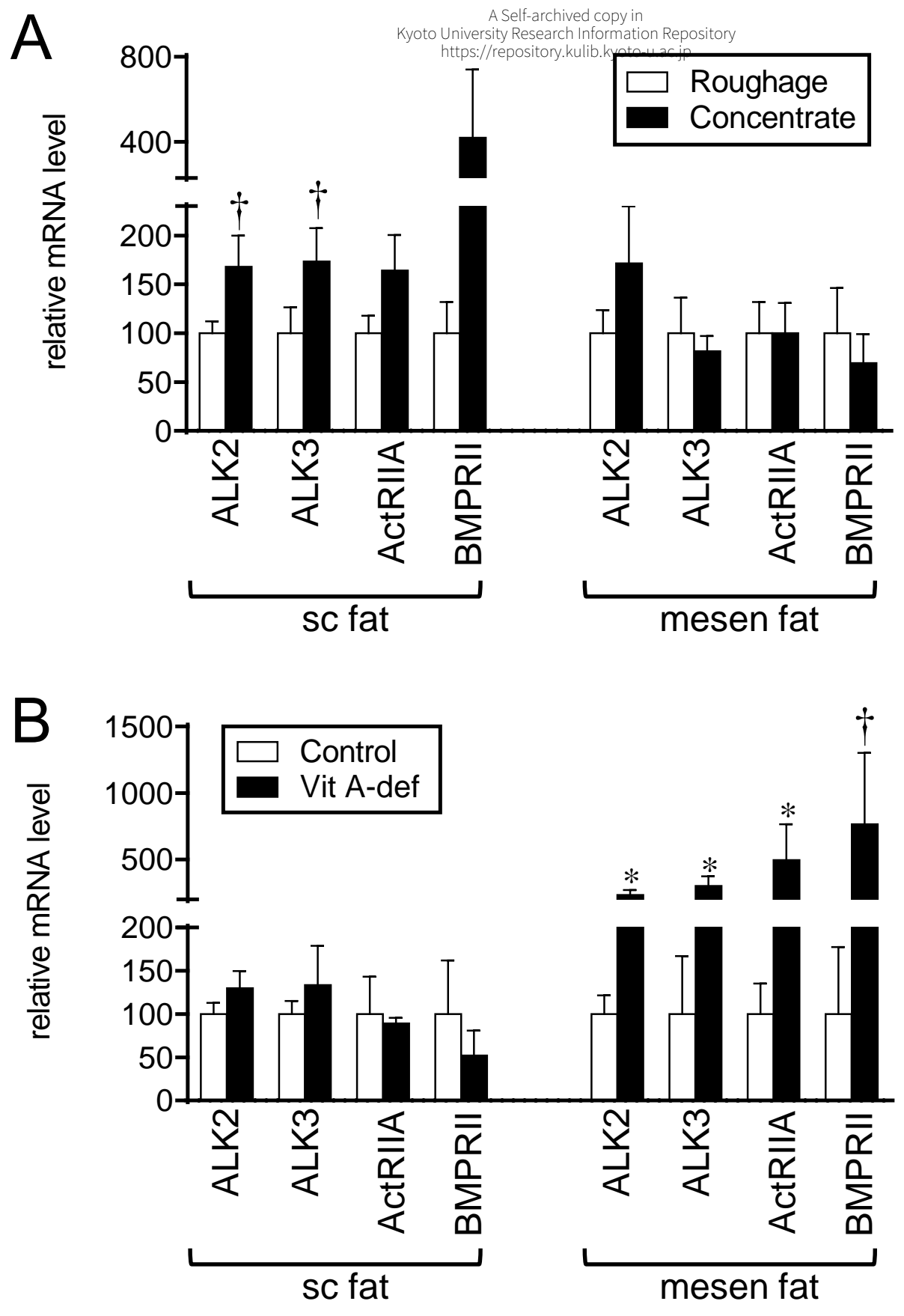